\title{
FinTech Market Development Perspectives
}

\author{
Ekaterina Kalmykova $^{1, \mathrm{a}}$, Anna Ryabova ${ }^{1}$ \\ ${ }^{1}$ Tomsk Polytechnic University, 634050 Lenin Avenue, 30, Tomsk, Russia
}

\begin{abstract}
Fast development of technologies has led to emergence of the new market - FinTech - which is very attractive for investors today. By now this market has a great number of different concepts: P2Pcrediting, E-wallets, Bitcoins, mPOS-acquiring, T-commerce, mobile banks, etc. Many of these tools have already heavily entered our ordinary life. People can obtain any credits through special services on the Internet from other users without participation of banks, pay by credit card using mobile devices, and get information about expenses and incomes according to the card anywhere in the world. Users do not need to go to banks anymore and to spend their time for credit arrangements, currency exchange, to look for ATMs to remove cash. Purchases on the Internet can be paid not only in rubles, but also in new digital currency. These tools make life easier, however, they pose a serious threat for banks. Now, bank institutions should create more convenient and utility services for the clients to keep clients. Therefore, bank and credit systems start to change actively.
\end{abstract}

\section{Introduction}

Nowadays, FinTech market, or the market of financial technologies, is one of the most active growing markets in the world.

Financial technology is a sector of economic where companies offer different financial services by using new technologies to make this process more efficient for themselves and more convenient for customers.

FinTech market has already many tendencies. The most popular among them are P2P lending, E-wallets, Bitcoins, mPOS acquiring, T-commerce, M-wallets (mobile banking), etc. At first sight it seems that there is no familiar concept which you have ever met. However, after a proper review, it will be obvious that many people have faced some of these financial technologies in one way or other.

Financial, monetary and credit systems are changing so quickly because of the fast technology development. There are many coming conversions from some elements to more modern ones, e.g. from cash to E-wallets or from bank credits to borrowing money through the Internet by other users. That is why banks have to create time after time new lending instruments to keep their clients.

Therefore, FinTech market is not only new possibilities and perspectives for start-up companies, but

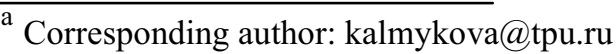

also a threat for traditional financial institutes such as banks and credit agencies.

\section{FinTech types}

Before examining the main types of fintech, the establishment of FinTech, which was started by Silicon Valley, should be explained. It is a place where most of IT projects have been designed and which later were treated as a sort of "accelerator" to modern financial technologies. Today it is London that is known as the capital of FinTech because of the number of fintech innovations and its investment flow. Great Britain has four main factors determined to encourage the development of FinTech: intensive infrastructure, a literate legal framework, a verifiable tax system and investment support in the country.

As has been noted above, FinTech was engendered in the USA and Europe earlier than in Russia. It came to domestic market only in 2008 when cellular operators took part in the development of mobile payments. Today the Russian market of FinTech is still in arrears of foreign markets, but it grows actively.

We will start with P2P lending, very widespread technology now. This abbreviation is interpreted as "peer-to-peer" or "person-to-person" lending, i.e. lending from one person to another. This term means there are only two participants (in most cases they are 
natural persons) in the process of loan granting without any intermediary agents such as banks and credit institutions. There are special web sites where a user can be a borrower as well as a lender. The biggest part of providing credits within such services belongs to not assured private loans. However, sometimes the involvement of companies (legal bodies) is also possible.

In case of $\mathrm{P} 2 \mathrm{P}$ lending, risk is higher because it is impossible to check the real credit history of a borrower in most cases and to make his/her loan scoring. Correspondingly, interest rates for these credits will be relatively overstated. Thus creditors prefer to lend many small loans to many loaners to decrease their non repayment risks.

Zopa (Zone of Possible Agreement) which was founded in 2005 in the UK became the first P2P lending service in the Internet. In a year, USA had also some P2P companies, e.g. Prosper and Lending Club. In Russia, these technologies appeared only in 2010 but they started functioning only two years later. At present there is credit exchange house which is based on the Webmoney service and another one is Vdolg.ru, a project of Banki.ru.

Another very popular financial technology is Ewallet or electronic wallet which allows paying for any goods and services through the Internet. Specifically for developing this concept, there is an official law which runs up the maximum size of possible sum of money in your E-wallet - from 100,000 rubles to 400,000 rubles. So, now it is multiplied by four. Russian market of Ewallets have 6 players who get the more active positions - five of them are domestic service (Webmonety Transfer, Yandex.Money, QIWI, RBK Money, Dengi@mail.ru), the last one is foreign (International money-transfer system PayPal).

One of the most popular electronic systems in CIS (Commonwealth of Independent States) is Webmoney Transfer oriented to money exchanging and conducting transactions of online currency. It offers a lot of functions, opportunities and operations on finance instantly produced.

The second famous payment system in CIS is Yandex.Money which provides safety exchange and transfer of online currency to other users keeping all necessary data about your operations.

The next Russian service on this market is QIWI functioning today in more than 20 countries all over the world. It specializes on instantaneous payments of any services including various utility bills, banking credits, etc. However, in contradistinction to other payment systems, this one has a feature - special self-service payment terminals. So you can pay for your bills not only through the Internet or by your mobile phone.

RBK Money or RUpay is a single payment platform working in real time mode. With this service a person can make any operation on his/her online money fast and safely. The main purpose of this technology is paying for bills and purchases through the Internet, cashing out.

The last domestic company among the abovementioned players is Dengi@mail.ru which confines itself to its interface. Payments are possible for making with the use of any personnel computer or device because the only thing that users need for their identification is e-mail.

International money-transfer system PayPal is a serious foreign competitor for Russian companies. It is one of the most popular services of the world; it was based in 1998 and nowadays it is used by more than 100 million users. Within this system users register simply their private account; major customers can set up a business account. In Russia PayPal is available only when paying for shopping. Electronic currency cannot be taken out or be admitted from other users.

Apart from E-wallets allowing controlling the purse strings online, completely numerical P2P currency Bitcoin - was created. It is intended to be a substitute for cash when you do shopping on the Internet. Unlike most of the types of e-money, which are kept on bank deposits and transferred with the aid of different payment systems, bitcoins are used outright between clients without any intermediary agents. That is why bitcoins have become a real direct rival for native currencies.

Today paying by credit cards for shopping is an everyday occurrence. Nevertheless, shops have to set up special POS-terminals to make transactions with credit cards. At small shops, stands, kiosks there is a difficulty in providing such terminals; that is why there is a necessity in cash all the time to buy any products. To solve this problem there is a new technology - Mobile Point of Sale - or mPOS terminal for short.

The terminal is represented as a computer device, which users have to connect to their mobile phone or tablet computer, and it allows doing cashless transfers by user's credit card. It is especially valuable for small and portable business, sole traders. For example, delivery agents of any products or documents can use this technology device to get refund for delivery on site. It is very convenient for a company as well as for clients because they do not need to withdraw money before making the order. By dint of mPOS terminals many firms are able to increase their profitability, for that reason their demand is very high on the market. By the way, investment analysts also mark the active growth of these devices. For example, according to Smart Insights research the number of mPOS terminals will exceed the number of POS terminals and will have achieved 52 million pieces by 2018 [1].

The leader of this field in Russia is LifePay. The project has gained more than 6 thousand users for a half year. During 2013, the total sum of money of all transactions, which were made by the mPOS readers, was more than $\$ 1 \mathrm{~m}$. The most successful mPOS companies on the world market are Square, SumUp, iZettle, mPowa.

Regarding the use of smart phones and tablet computers for conducting any financial transactions, it is necessary to mention another concept - T-commerce which is directly concerned with modern gadgets. It stands for tablet-commerce. This term was coined by specialists from Silicon Valley due to the fact of the beginning of the "mobile" era in economy. Steady growth on mobiles and tablets market is registered all over the world, so it is fertile ground for t-commerce evolution. 
Furthermore, mobile banking is also developing. According to The Economist and NY Times the next generation of banks, which have only a mobile version (e.g. Simple, Moven), wins from traditional banks because of the new customer generation. There is a similar trend in Russia. Mobile banking has some advantages: the work place is where the customer is; a clients can monitor their balance of account; they have an access to their personal manager, revenues and expenses analytics.

\section{New perspectives, new competitors}

Fast growth of technologies and FinTech extension surely attract attention of investors. It is also justified by numbers - in comparison with 2013, in 2014 global venture investments on this market have grown to $\$ 12$ billion that is 3 times more than the indicators of the previous year. Just for the record, Europe is the most fast-growing FinTech region in the world. In 2014 the growth of the investments share into financial technologies amounted to $215 \%$ [2].

One of the reasons of such rise is credit deficit. The population often needs more and more small loans which are not attractive for banks because of their low profitability and which have higher risks. It causes good prospects for the companies in the sphere of $\mathrm{P} 2 \mathrm{P}$ crediting.

Cross-border personal loans become the interesting P2P-crediting sphere, e.g. Russians can obtain the credits through these services from inhabitants of Europe. The average interest rate in Russia fluctuates around $25 \%$. Deposit rates in Europe are about $0,5 \%$ a year [3], i.e. profitability is very low. Therefore, Europeans can extend credits to Russians on a higher rate than the deposit rates in Europe, but, at the same time, lower, than interest rates in Russia [4]. Thus, such loans are more favourable for both sides.

It should be noted that the active growth of technologies in the financial segment is going to be threatening for banks and credit institutes. Therefore, almost every tenth Russian bank was closed in 2015 because of process inefficiency and lack of innovations [5]. Banks have to create better and more convenient products and services for their clients to survive. If traditional suppliers on financial market do not switch to new technologies, their target audience will pass to more utility and cheap services. At the moment there are only about ten banks in Russia among others who have mobile applications for customer service.

While banks have disadvantages relatively start-ups, they also have advantages. Being regulated is a burden in many ways, it creates consumer confidence. A long history brings legacy systems with it and also builds trusted brands (albeit tested by the global financial crisis) and provides rich historic data, not to mention a banking license and a sizable head start in compliance initiatives. And, of course, banks understand banking; especially the risks involved, which new entrants often do not [5].

Looking forward, there will be a new business model of profit-making as a result of possible cooperation between traditional banks and innovative start-ups [2]. The strengths and weaknesses of both banks and fintechs mean that both will often do better by cooperating rather than by competing.

Besides the development of "credit" technologies, there is other interesting segment for the Russian market - personal data. For example, Sberbank knows the size of clients' salary, how much money they withdraw, where and on what they spend it. And the only one who gets more data than bank is a mobile service provider how much time is spent on talks and with whom, how much time the subscriber is located abroad, what additional services are used. All these personal data is a part of additional financial services promotion, and also a part of how these services will develop analytics.

Today it is a topic of the hour in the West. All large mobile service providers (e.g. AT\&T, Vodafone, TMobile) are already engaged in handling of such data. In Russia this direction is only arising. The combination of FinTech market and the collection of personal data offers great perspectives for further economic development in general.

\section{Legal difficulties}

In spite of the fact that fintech market is spreading quickly today and there are many new start-ups every month, there is still no legal regulation by the government. Financial technologies develop so fast that it is difficult to manage all its innovative features in case of legal control. However, it is a problem not only for government but for start-upers and customers as well. Thus, fintech regulation is becoming a global issue.

Today many countries have special institutes to control firms on the financial market. For example, in the UK there is Financial Conduct Authority (FCA), an independent non-government body. FCA has the power to regulate firms in the financial sector and its responsibilities are applying standards and requirements for financial products, regulating marketing and financial products' conduct, investigating firms and applying bans where they seem to be appropriate. It regulates such players of the market as banks, credit companies, mutual societies and financial advisors. Thereby it is free to control some of fintech start-ups.

The UK regulates certain activities conducted in relation to a range of payment, investment and lending propositions, which means, as a general rule, a FinTech business needs to consider at an early stage whether it requires regulatory approval to conduct business in the UK. A surprising range of business models need regulatory approval to operate in the UK - even when they are not based in the UK.

The FCA's application process, if managed well, need not be overly complicated or intrusive. The typical authorization timeframe with appropriate resources in place can comprise a six-week pre-submission preparation period, followed by a statutory postsubmission period (of up to six months) for FCA to consider the application [6]. 
Regarding the USA, there are other instruments of regulation. The U.S. Securities and Exchange Commission (SEC), for instance, is an agency of the U.S. federal government, which is the main control authority within securities market in the United States. It holds primary responsibility for enforcing the federal securities laws, proposing securities rules, regulating the securities industry and so on.

One of acts enforced by SEC is the Securities Act of 1933, a federal act according to which investors can be informed about investments and which allows establishing laws against misrepresentation and fraudulent activities in the securities markets. For companies working with investments, the Act should be very important, because in case of its breach a company would face not only civil, but also criminal charges. In that way, lending companies, such as "Prosper" or "Lending Club", had to register securities with SEC, because in 2008 SEC decided their activities to be in violation of the Securities Act of 1993 - the peer-to-peer loans the companies provided to earn a profit in the form of interest were at a rate higher than that available from depository accounts at financial institutions [7].

Last year SEC announced a new set of rules implementing Title IV of the JOBS Act or the Jumpstart Our Business Startups Act, which intend to encourage funding of the U.S. small businesses by easing various securities regulations. These new rulings will be done initially through what are called Regulation $\mathrm{A}+$ investment offerings. According to this fact, now, more people can take part in early-stage investment, and companies are able to increase their capital with less regulatory burdens. For FinTech market, these rules are really important and very helpful when developing new platforms. Thus, fintech startups will be responsible for complying with the regulations but with no case law yet to guide them while investors will still be limited in how much they can invest and with whom [8].

Apart from SEC, there is also Financial Industry Regulatory Authority, Inc. (FINRA) which regulates the members of brokerage firms and exchange markets. Contrary to SEC, FINRA is a non-governmental organization and, moreover, it is the successor to the National Association of Securities Dealers (NASD) and regulation of the members' enforcement and arbitration operations of the New York Stock Exchange.

When considering loaning money to individuals whether as a creditor or within the investment process, lending laws appear. Usually these laws are set at the state level, and they restrict such actions as who you can lend to, how much you can lend and the interest rates charged to borrowers. Each fintech startup in the USA should take care to comply with lending laws that go hand in hand with securities regulations [9].

Unfortunately, Russia has still no legal regulation of fintech. It is connected to its later coming to the Russian market. Nevertheless, the Central Bank is an active participant of fintech development in Russia. At the same time, the most attractive and challenging fintech project for the Central Bank is Bitcoin, of course. Firstly, the Bank wanted to abolish the digital currency and make using Bitcoin punishable by law. Then the Bank decided to explore the possibilities and boundaries of the Bitcoin technology.

Some time ago, the Central Bank announced that it wanted to be a part of Fintech evaluation in Russia. It has already set up a taskforce for the sole purpose of exploring what can be done in the short and long run. The taskforce will hold regular meetings to discuss the technologies they discovered and in what way they can be useful to the Bank of Russia [10]. Today it is also creating a self-regulating board that allows industry players to collaborate on fintech efforts with others [11].

\section{Conclusion}

It is possible to sum up that the modern FinTech tools have a considerable impact on the economies of different countries, in particular, on banks and credit systems. On the one hand, they pose a threat for banks and credit institutes as they actively drive them out from the market due to their modernity and utility. However, on the other hand, it is possible to tell that financial technologies increase the quality of the services provided by banks and give an impetus to their productive development towards informatization.

There is no doubt that the fintech regulation is not still ready for total control of new startups and their technologies. Despite this fact, there are a great number of upcoming trends now which will probably lead to a new economic business model in the end.

\section{Acknowledgment}

This research was financially supported by National Research Tomsk Polytechnic University.

\section{References}

1. Smart Insights, Mpos market dynamics will reduce traditional pos sales by 10 million units according to smart insights report, (2014). Available from: http://www.smartinsights.net/Company/Ournews/mPOS-market-dynamics-will-reducetraditional-POS-sales-by-10-million-unitsaccording-to-Smart-Insights-Report

2. Assotiation of Russian Banks (ARB), FinTech kompanii - konkurenty ili partner, (2015). Available from: http://arb.ru/b2b/trends/fintech_kompanii_ konkurenty_ili_partnery-9902037

3. European Central Bank, Key ECB interest rates Available from: https://www.ecb.europa.eu/stats /monetary /rates/html/index.en.html

4. A. Turkot, «Startapy segodnya - sbitye letchiki, upavshie s nebes na zhestkuyu zemlyu», (2015). Available from: https://roem.ru/14-042015/191993/turkot-fintech

5. S.I.Ventures, O. Wyman, Anthemis Group, The Fintech 2.0 Paper: rebooting financial services, (2015). Available from: $\mathrm{http}: / /$ santanderinnoventures.com/wpcontent/uploads/2015/06/The-Fintech-2-0-Paper.pdf 
6. C. Woolard, UK FinTech: Regulating for innovation, (2016). Available from: https://www.fca.org.uk/news/uk-fintech-regulatingfor-innovation

7. L. Downes, Five legal threats for fintech's hottest start-ups (The Washington Post, 2015). Available from: https://www.washingtonpost.com/news/ innovations/wp/2015/08/27/five-legal-threats-forfintechs-hottest-start-ups/

8. Priori Legal, Securities Regulation for FinTech Startups. Available from: https:/www.priorilegal.com/securities/securitiesregulation-for-fintech-startup

9. N. Athwal, Fintech Startups Navigate Legal Gray Areas To Build Billion-Dollar Companies, (2015). Available from: http://techcrunch.com/2015/04/19 /fintech-startups-navigate-legal-gray-areas-to-buildbillion-dollar-companies/

10. OneStopBrokers, Bank of RussiaSets up Teskforce to Explore Bitcoin and FinTech, (2016). Available from: http://www.onestopbrokers.com/2016/02/29/ bank-russia-sets-taskforce-explore-bitcoin-fintech/

11. R. Kennedy, Bank of Russia Pushes for Fintech (Payment Week, 2016). Available from: http://paymentweek.com/ 2016-3-3-bank-of-russiapushes-for-fintech-9812/ 